\title{
DIVERSITY OF AIR TEMPERATURE IN POLAND IN THE YEARS 1971-2010
}

\author{
Joanna Krużel' ${ }^{1}$ Agnieszka Ziernicka-Wojtaszek' \\ 1 Department of Ecology, Climatology and Air Protection, Faculty of Environmental Engineering and Land \\ Surveying, University of Agriculture in Kraków, al. Mickiewicza 24/28, 30-059 Kraków, Poland, e-mail: \\ joannakruzel90@gmail.com, aziernik@poczta.fm
}

Received: 2016.08.01 Accepted: 2016.09.26 Published: 2016.11.01

\begin{abstract}
The article presents the changes in the values of average air temperature and its spatial diversity in the four seasons of the year (spring, summer, autumn, winter) in the years 1981-2010 compared with the 1971-2000 period. In the 1981-2010 period (the new climate normal currently in force) the largest increase in air temperature expressed in the average area value occurred in summer and reached $0.5^{\circ} \mathrm{C}$. In spring and autumn the increase in average air temperature was smaller and was $0.4^{\circ} \mathrm{C}$ and $0.3^{\circ} \mathrm{C}$ respectively; in winter average temperature did not change compared with the previous climate normal.
\end{abstract}

Keywords: temperature, climate change, climate normals, Poland

\section{INTRODUCTION}

According to the guidelines of the World Meteorological Organization (WMO) the climate of a given area is usually described on the basis of long-term, usually thirty-year periods. So far they have been the following periods: 1901-1930, 1931-1960 and 1961-1990. In the light of a distinct increase in temperature observed in the world and in Poland especially in the past four decades in the intensified process of global warming [Kożuchowski and Żmudzka 2001, Solomon et al. 2007, Milly et al. 2008, Ziernicka-Wojtaszek 2009, Żmudzka 2009, Michalska 2011] and in the local aspect [Michalska 2009, Gregorczyk and Michalska 2011, Kasperska-Wołowicz and Bolewski 2015, Kaszewski and Bilik 2015] the point of describing the current, and even more so, future climate conditions by means of 30-year normals has started to be questioned recently [Livezey et al. 2007]. That is why, in order to update climate descriptions, according to the WMO instructions, the thirty-year climate normals are changed - replaced with new ones - not every thirty years but every ten years. Instead of the next norm 1991-2020, the norm 1971-2000 is applied, and recently 1981-2010 [Arguez and Vose 2011]. As regards atlases of
Poland's climate, apart from the old atlases by Wiszniewski et al. [1949] and Wiszniewski [1953, 1973] there is the Atlas klimatu Polski by Lorenc [2005] which includes cartographic illustration of basic climate elements and indices without tables for the previous climate normal 1971-2000. Despite the announcements that efforts have been made to update and reissue the Atlas, there is no description of Poland's climate within the new official climate normal 1981-2010 and no comparison with the previous normal which would allow to follow the changes. The presented work attempts to meet the signaled needs. The aim of the work was to describe the spatial diversity of air temperature in Poland in individual climatological seasons of the year in the new climate normal 1981-2010 and to compare the diversity with the previous normal 1971-2000.

\section{MATERIALS AND METHODS}

The work uses meteorological data concerning average monthly values of air temperature from 53 meteorological stations for the period of 1971-2010, evenly distributed in Poland. The data was obtained from Monthly Meteorological 
Reviews, Decade Agrometeorological Bulletins and from unpublished archive materials from the Polish Institute of Meteorology and Water Management (IMGW). The obtained data allowed to calculate average values of air temperature for 4 climatological seasons of the year. Those seasons include 3 calendar months each: March, April, May (spring), June, July, August (summer), September, October, November (autumn) and December, January, February (winter). The spatial diversity of the average values of air temperature in Poland was shown in the mentioned seasons in two climate normals 1971-2000 and 1981-2010 and then comparison was made of the changes in the values of the meteorological element under discussion. Mountain areas were omitted on account of insufficient number of meteorological stations necessary to describe these areas.

\section{RESULTS}

The average annual temperature in spring in the years $1971-2000$ in Poland was $7.8^{\circ} \mathrm{C}$ (Table 1). In the 1971-2000 period the hottest regions with air temperature equal to or greater than $8.5^{\circ} \mathrm{C}$ were recorded in the Silesian Lowlands, the Sandomierz Basin around Tarnów, in the eastern part of the Silesian-Lusatian Lowlands and in the Lubuskie Lake District around Stubice. In the 1981-2010 period the area of Poland with the air temperature $8.5^{\circ} \mathrm{C}$ or more increased significantly. In this period such temperature was also recorded in the Szczecin Lake District, the Greater Poland Lake District, the South Greater Poland Lowlands, the Western Beskid Mountains, the Kielce Uplands, the Woźniki-Wielun Uplands and in the eastern

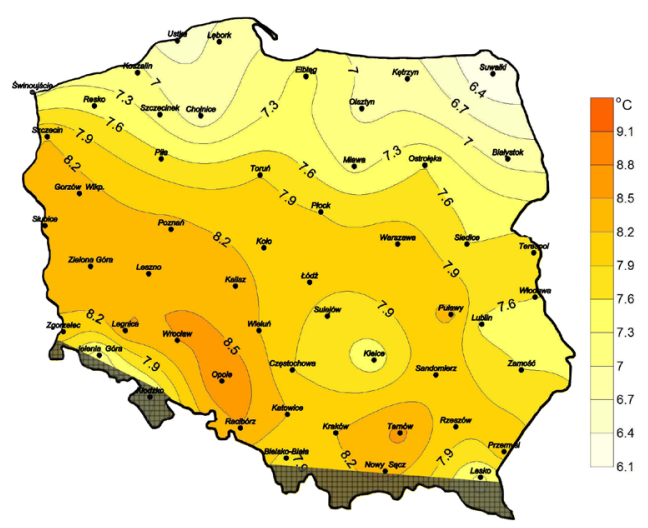

Fig. 1. Average air temperature in spring in Poland in the years 1971-2000 part of the Southern Mazovia Hill. In both compared normals 1971-2000 and 1981-2010 the hottest place was Opole and the coldest Suwałki. The average air temperature in Opole was $8.8^{\circ} \mathrm{C}$ and $9.1^{\circ} \mathrm{C}$ respectively, and in Suwałki $6.1^{\circ} \mathrm{C}$ and $6.6^{\circ} \mathrm{C}$ respectively. The coldest regions in the periods 1971-2000 and 1981-2010 covered the area of the Lithuanian Lake District, the Koszalin coast and the vicinity of Jelenia Góra and Kłodzko (Fig. 1, Fig. 2).

The hottest regions with summer temperature $17.2^{\circ} \mathrm{C}$ and higher in the $1971-2000$ period and $17.8^{\circ} \mathrm{C}$ and higher in the $1981-2010$ period cover the area of the Greater Poland Lake District, the Greater Poland Lowlands, the Silesian Lowlands, the eastern part of the Central Mazovia Lowlands and the Sandomierz Basin. The stations with the highest summer temperature in the former thirtyyear period are Opole and Puławy with the temperature $17.7^{\circ} \mathrm{C}$; in the latter thirty-year period it is also Opole and Puławy with the temperature $18.3^{\circ} \mathrm{C}$, Tarnów $18.2^{\circ} \mathrm{C}$ and Wrocław $18.1^{\circ} \mathrm{C}$. The lowest air temperature in the years 1971-2000 and 1981-2010 occurred in Jelenia Góra, reaching $15.7^{\circ} \mathrm{C}$ and $16.3^{\circ} \mathrm{C}$ respectively. The coldest areas in both compared normals were the mountainous basins of southern Poland, the Koszalin Coast and the Suwałki Lake District represented by the stations in Jelenia Góra, Kłodzko, Ustka and Suwałki (Fig. 3, Fig. 4).

In autumn in Poland the average air temperature in the years 1971-2000 fluctuated between $6.5^{\circ} \mathrm{C}$ and $9.1^{\circ} \mathrm{C}$. The air temperature of $8.6^{\circ} \mathrm{C}$ and higher occurred in the Silesian Lowlands, the Silesian-Lusatian Lowlands, the Zielona Góra Hill, the Sandomierz Basin around Tarnów, in the western part of the Thorn-Eberswalde Urstrom-

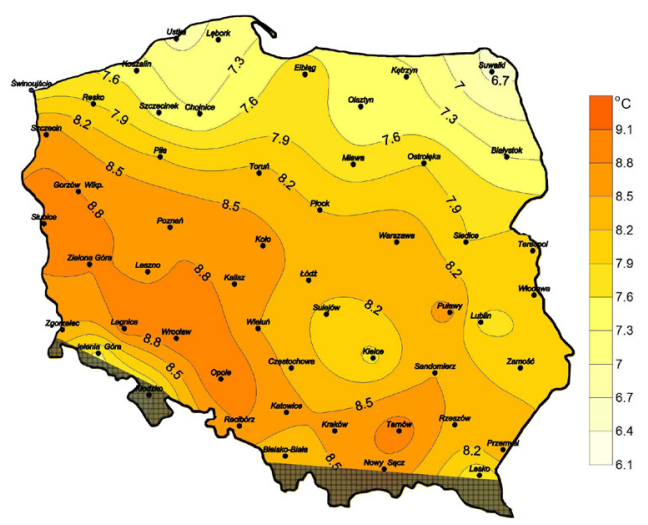

Fig. 2. Average air temperature in spring in Poland in the years 1981-2010 


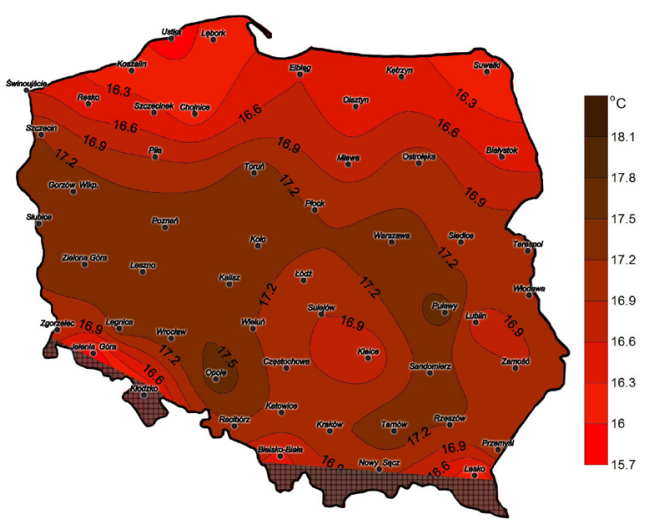

Fig. 3. Average summer air temperature in Poland in the years 1971-2000

tal, on the Szczecin Coast and the Koszalin Coast. They were the hottest areas in the season under discussion. In the years 1981-2010 the average air temperature in autumn reached $6.8^{\circ} \mathrm{C}$ to $9.4^{\circ} \mathrm{C}$, thus being on average $0.3^{\circ} \mathrm{C}$ higher than in the previous analyzed thirty-year period. The hottest places in Poland in the 1981-2010 period with the temperature higher than $8.6^{\circ} \mathrm{C}$ apart from the regions mentioned in the previous period were the Greater Poland Lake District, the South Greater Poland Lowlands, the Silesian Uplands, the Woźniki-Wielun Uplands and the Western Beskid

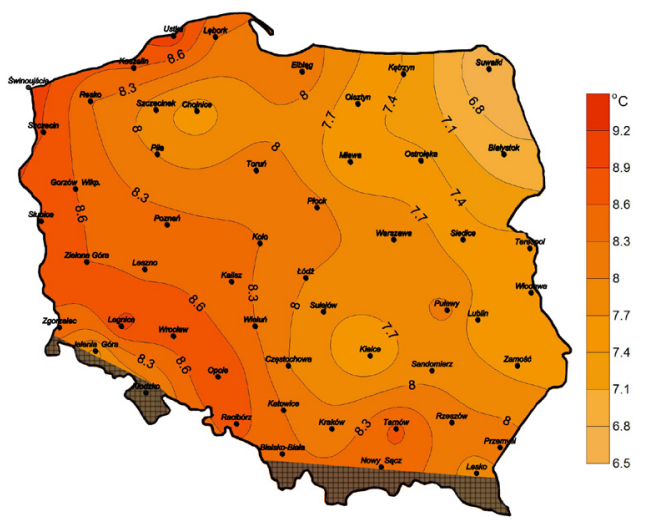

Fig. 5. Average autumn air temperature in Poland in the years 1971-2000

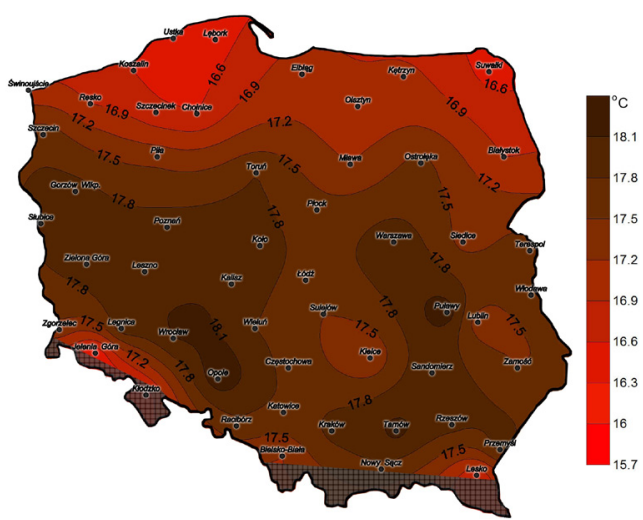

Fig. 4. Average summer air temperature in Poland in the years 1981-2010

Mountains. In the years 1971-2000 the coldest regions with the air temperature lower than $7^{\circ} \mathrm{C}$ covered the area of Suwałki and Białystok and in the 1981-2010 period only the vicinity of Suwałki (Fig. 5, Table 1, Fig. 6).

In winter in the years 1971-2000 and 1981-2010 the highest air temperature occurred in Świnoujście, reaching $0.8^{\circ} \mathrm{C}$ and $0.9^{\circ} \mathrm{C}$ respectively, and the lowest in Suwałki: $-3.2^{\circ} \mathrm{C}$ and $-3.0^{\circ} \mathrm{C}$. The highest values of the average winter temperature in both climate normals were recorded in western Poland on the Szczecin Coast,

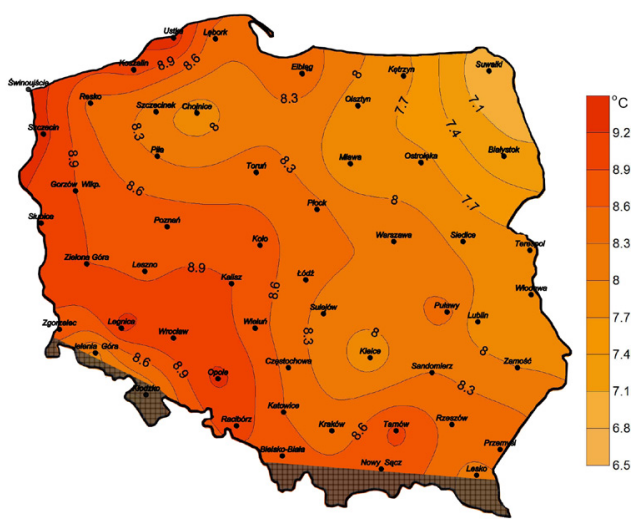

Fig. 6. Average autumn air temperature in Poland in the years 1981-2010

Table 1. Average area values of air temperature in the climatological seasons of the year in the years 1971-2000 and 1981-2010 in Poland

\begin{tabular}{|c|c|c|c|}
\hline Seasons of the year & $1971-2000$ & $1981-2010$ & $\begin{array}{c}\text { Increase in the average area } \\
\text { value of air temperature }\end{array}$ \\
\hline Spring & $7,8^{\circ} \mathrm{C}$ & $8,2^{\circ} \mathrm{C}$ & $0,4^{\circ} \mathrm{C}$ \\
\hline Summer & $16,9^{\circ} \mathrm{C}$ & $17,4^{\circ} \mathrm{C}$ & $0,5^{\circ} \mathrm{C}$ \\
\hline Autumn & $8,1^{\circ} \mathrm{C}$ & $8,4^{\circ} \mathrm{C}$ & $0,3^{\circ} \mathrm{C}$ \\
\hline Winter & $-0,9^{\circ} \mathrm{C}$ & $-0,9^{\circ} \mathrm{C}$ & $0,0^{\circ} \mathrm{C}$ \\
\hline
\end{tabular}


the Koszalin Coast, in the Western Pomeranian Lake District, the western part of the Thorn-Eberswalde Urstromtal, the Silesian Lowlands around Wrocław, in the Silesian-Lusatian Lowlands, the Western Sudeten Plateau, the Lubuskie Lake District around Stubice. The lowest, sub-zero temperatures occurred in the Lithuanian Lake District, the Mazurian Lake District, the Old Prussian Lowlands and the Northern Podlasie Lowlands and the Western Polesie (Fig. 7, Fig. 8).

The average air temperature in Poland in the years 1981-2010 irrespective of the spatial diversity in summer was $17.4^{\circ} \mathrm{C}$ and was higher by $0.5^{\circ} \mathrm{C}$ than the average in the $1971-2000$ period. In spring and autumn the increase of its average value was smaller: $0.4^{\circ} \mathrm{C}$ and $0.3^{\circ} \mathrm{C}$ respectively. In winter in both analyzed periods the average value of temperature was the same: $-0.9^{\circ} \mathrm{C}$ (Table 1 ).

\section{DISCUSSION AND CONCLUSIONS}

Research by many authors [Kożuchowski and Żmudzka 2001, Zawora 2005, ZiernickaWojtaszek and Zawora 2008, Michalska 2009 and 2011] confirms a distinct increase in air temperature observed since the last two decades of the 20th century. Michalska [2011] shows that the average annual air temperature in the years 1951-2005 in the greater part of the country rose by ca. $0.2^{\circ} \mathrm{C}$ per decade. The pace of the air temperature increase in Poland in the years 1951-2010 was already $0.22^{\circ} \mathrm{C}$ per decade [Wójcik and Miętus 2014]. Considering a shorter research period, namely 1971-2010, Krużel [2014] proved an increase in temperature of $0.3^{\circ} \mathrm{C}$ per decade. This complies with the pace of the increase in global

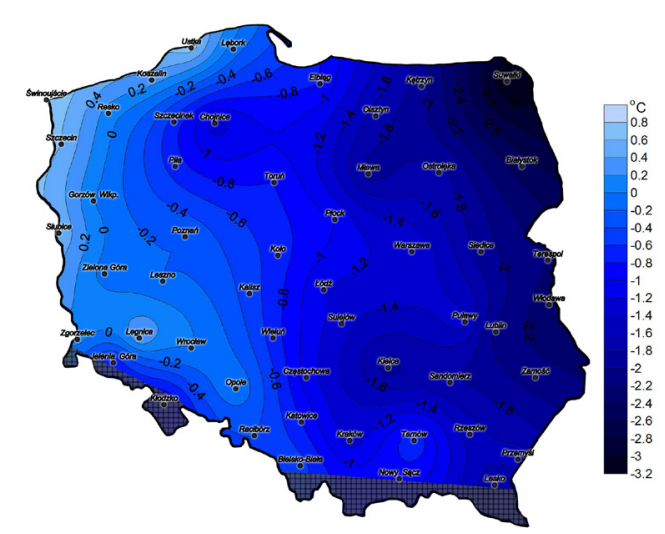

Fig. 7. Average winter air temperature in Poland in the years 1971-2000 temperature, which is becoming faster and faster. The pace of warming is increasing. In the past 150 years it has been $0.045^{\circ} \mathrm{C} /$ decade, in the past 100 years $0.074^{\circ} \mathrm{C} /$ decade, in the past 50 years $0.128^{\circ} \mathrm{C} /$ decade and in the past 25 years $0.177^{\circ} \mathrm{C} /$ decade [Intergovernmental Panel on Climate Change 2007]. Even higher values are presented in the V IPCC Report [2014] for the 1979-2012 period $-0.26^{\circ} \mathrm{C} /$ decade. In the newest climate normal 1981-2010 compared with the previous normal the pace of the warming in particular seasons of the year presents itself differently. If for the 1951-2010 period [Wójcik and Miętus 2014] the increase in temperature per decade in particular seasons from spring through summer and autumn to winter was successively $0.36^{\circ} \mathrm{C}, 0.19^{\circ} \mathrm{C}$, $0.06^{\circ} \mathrm{C}$ and $0.32^{\circ} \mathrm{C}$, the decade increase in temperature between the new and old norm, i. e. between the periods $1971-2000$ and 1981-2010 was $0.4^{\circ} \mathrm{C}, 0.5^{\circ} \mathrm{C}, 0.3^{\circ} \mathrm{C}$ and $0.0^{\circ} \mathrm{C}$. Unlike the 1951-2010 period the largest increases occurred not in winter but in summer, whereas in winter there were no differences.

The carried out research allowed to reach the following conclusions:

1. In the 1981-2010 period the largest increase in air temperature expressed by the average area value occurred in summer and was $0.5^{\circ} \mathrm{C}$ compared with the 1971-2000 period.

2. The spring and autumn increases were $0.4^{\circ} \mathrm{C}$ and $0.3^{\circ} \mathrm{C}$ respectively. In winter no changes in the average area temperature value were recorded compared with the previous normal 1971-2000.

3 . The spatial distribution of the air temperature in the years 1971-2000 and 1981-2010 shows an increase in the values of isolines in summer

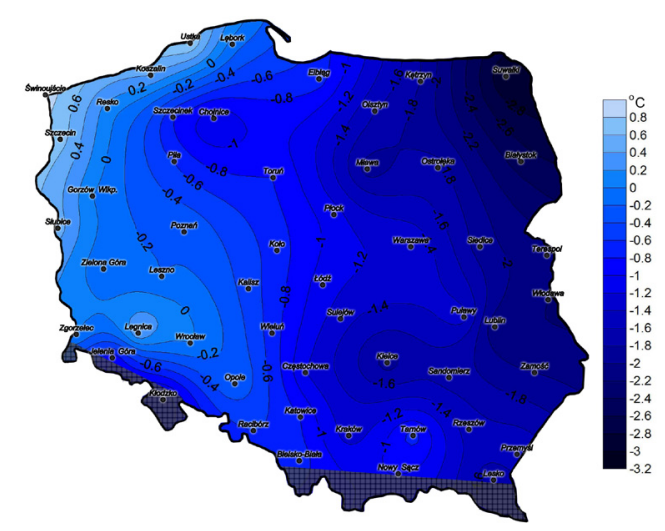

Fig. 8. Average winter air temperature in Poland in the years 1981-2010 
and spring from the north southwards, and in autumn and winter from the east westwards.

4. Irrespective of the season, the highest average temperature was recorded in the western part of Poland.

5. In both analyzed climate normals 1971-2000 and 1981-2010 the highest average long-term air temperature in summer occurred in Opole and Puławy, in spring only in Opole and in autumn and winter in Świnoujście. The lowest air temperature was recorded in Suwałki, except for the summer, when the lowest temperature occurred in Jelenia Góra.

\section{Acknowledgements}

The research was carried out under the theme No. 4393, were financed from the special purpose grant for science awarded by the MNiSW.

\section{REFERENCES}

1. Arguez A., Vose R.S. 2011. The Definition of the Standard WMO Climate Normal. Bulletin of the American Meteorological Society, June, 699-704.

2. Gregorczyk A., Michalska B. 2011. Zmienność temperatury powietrza w Szczecinie w latach 1949-2008. Acta Agrophysica, 17 (2), 301-309.

3. Intergovernmental Panel on Climate Change. 2007. The Fourth Assessment Report.

4. Intergovernmental Panel on Climate Change. 2014. The Fifth Assessment Report.

5. Kasperska-Wołowicz W., Bolewski T. 2015. Zmienność temperatury powietrza w Bydgoszczy w latach 1931-2013. Woda - Środowisko - Obszary Wiejskie, t.15, z. 3 (51), 25-43.

6. Kaszewski B.M., Bilik A. 2015. Zmiany średniej dobowej temperatury powietrza w Lublinie w latach 1951-2010. Annales Universitatis Mariae Curie-Skłodowska Lublin-Polonia. Sectio B, vol. LXX, z. 1, 71-82.

7. Kożuchowski K., Żmudzka E. 2001. Ocieplenie w Polsce: skala i rozkład sezonowy zmian temperatury powietrza w drugiej połowie XX wieku. Przegląd Geofizyczny, 46, 1-2, 81-90.

8. Krużel J. 2014. Ekologiczne i gospodarcze skutki współczesnych zmian termicznych cech klimatu Polski (1971-2010). Praca magisterska wykonana w Katedrze Ekologii, Klimatologii i Ochrony Powietrza. UR w Krakowie. Promotor dr hab. inż. Agnieszka Ziernicka-Wojtaszek.

9. Livezey R.E., Vinnikow K.Y., Timofeyeva M.M., Tinker R., Van den Dool H.M., 2007. Estimation and extrapolation of climate normals and climatic trends. Journal of Applied Meteorology and Climatology, 46, 1759-1776.

10. Lorenc H. 2005. Atlas klimatu Polski. IMGW, Warszawa, pp. 186.

11. Michalska B. 2009. Variability of air temperature in North western Poland. In: Z. Szwejkowski (Ed.), Environmental aspects of climate change, UW-M, Olsztyn, 89-107.

12. Michalska B. 2011. Tendencje zmian temperatury powietrza w Polsce. Prace i Studia Geograficzne, t. 47, 67-75.

13. Milly P.C.D., Betancourt J., Falkenmark M., Hirsch R.M., Kundzewicz Z.W. Lettenmaier D.P. Stouffer R.J. 2008. Stationarity is dead: whither water management? Science, 319, 573-574.

14. Solomon S., Qin D., Manning M., Marquis M., Avery M., Tignor M., Miller H.L., Chen Z. 2007. Climate Change 2007, The Physical Science Basis. Cambridge University Press, pp. 996.

15. Wiszniewski W., Gumiński R., Bartnicki L. 1949. Przyczynek do klimatologii Polski. Wiadomości Służby Hydrologicznej i Meteorologicznej, t. I. z. 5, cz. II, Warszawa.

16. Wiszniewski W. 1953. Atlas opadów atmosferycznych w Polsce 1891-1930. WKiŁ, Warszawa.

17. Wiszniewski W. (red.) 1973. Atlas klimatyczny Polski, PPWK, Warszawa.

18. Wójcik R., Miętus M. 2014. Niektóre cechy wieloletniej zmienności temperatury powietrza $\mathrm{W}$ Polsce (1951-2010). Przegląd Geograficzny 86, 3, 339-364.

19. Zawora T. 2005. Temperatura powietrza w Polsce w latach 1991-2000 na tle okresu normalnego 1961-1990. Acta Agrophysica, 6 (1), 281-287.

20. Ziernicka-Wojtaszek A. 2009. Weryfikacja rolniczo-klimatycznych regionalizacji Polski w świetle współczesnych zmian klimatu. Acta Agrophysica 13 (3), 803-812.

21. Ziernicka-Wojtaszek A., Zawora T. 2008. Zróżnicowanie pluwiotermiczne Polski w świetle współczesnych zmian klimatu. Acta Agrophysica, 12 (1), 289-297.

22. Żmudzka E. 2009. Współczesne zmiany klimatu Polski. Acta Agrophysica, (13) 2, 555-568.

Pracę dofinansowano ze środków Wojewódzkiego Funduszu Ochrony Środowiska i Gospodarki Wodnej w Lublinie. 